Mirjana KEVO, dipl. iur.

UDK: 341.3231.14 (4-67 EU)

doktorandica Pravnoga fakulteta Sveučilišta u Mostaru mirjana.kevo@pravosudje.ba

$342.565 .2(497.6)$

Pregledni znanstveni rad

Primljen: 25. 4. 2020.

Prihvaćen: 18. 5. 2020.

\title{
PRAVO NA NEOVISAN I NEPRISTRAN SUD PREMA ČLANKU 6. EUROPSKE KONVENCIJE ZA ZAŠTITU LJUDSKIH PRAVA I TEMELJNIH SLOBODA I U ZAKONODAVSTVU BOSNE I HERCEGOVINE
}

\begin{abstract}
Sažetak: Neovisnost i nepristranost sudova predstavlja jedan od najvažnijih uvjeta pravičnog postupka. Ustav, zakoni, pa i sama državna politika moraju osigurati postojanje takve sudbene vlasti koja će biti uistinu neovisna od ostalih grana državne vlasti. Čl. 6. stavak 1. Europske konvencije za zaštitu ljudskih prava i temeljnih sloboda navodi da svatko ima pravo na zakonom ustanovljeni neovisni i nepristrani sud. Inkorporiranjem Europske konvencije za zaštitu ljudskih prava i temeljnih sloboda u svoj ustavnopravni poredak Bosna i Hercegovina je preuzela obvezu da svoje zakonodavstvo prilagodi zaštiti prava iz te konvencije.

U radu će se analizirati praksa Europskog suda za ljudska prava u odnosu na pravo na zakonom ustanovljeni neovisan i nepristran sud. Ta praksa uspostavila je brojne kriterije koji jamče ostvarenje i provedbu ovog temeljnog pravnog načela. U drugom dijelu rada razmotrit će se pravo na zakonom ustanovljeni neovisan i nepristran sud u zakonodavstvu Bosne i Hercegovine. Potom će se pokušati odgovoriti na pitanje je li i u kojoj mjeri Bosna i Hercegovina uskladila svoje zakonodavstvo sa zahtjevima prava na pravično suđenje zajamčenog čl. 6. stavak 1. Europske konvencije za zaštitu ljudskih prava i temeljnih sloboda u odnosu na temeljno pravno načelo - zakonom ustanovljeni neovisan i nepristran sud.
\end{abstract}

Ključne riječi: neovisnost, nepristranost, sud, Europska konvencija za zaštitu ljudskih prava i temeljnih sloboda.

\section{Uvodne napomene}

Konvencija za zaštitu ljudskih prava i temeljnih sloboda Vijeća Europe (u daljnjem tekstu - EKLJP) usvojena je 4. studenoga 1950. godine u Rimu, a stupila je na snagu 3. rujna 1953. godine nakon što ju je ratificiralo deset prvobitnih država članica. Za svaku državu potpisnicu koja je EKLJP naknadno ratificirala 
ona je stupila na snagu na dan polaganja isprave o ratifikaciji. ${ }^{1}$ Danas su svih 47 država članica Vijeća Europe ujedno i stranke EKLJP, koja je u većini država članica, po svojo pravnoj snazi, iznad zakona. ${ }^{2}$

Konvencija je dijelom bosanskohercegovačkog pravnog poretka postala od 14 . prosinca 1995. godine stupanjem na snagu Ustava Bosne i Hercegovine, odnosno Aneksa 4 Daytonskog mirovnog sporazuma. Međutim, tek je njezinom ratifikacijom 12. srpnja 2002. godine Bosna i Hercegovina prihvatila nadležnost Europskog suda za ljudska prava u Strasbourgu (u daljnjem tekstu - ESLJP), a ujedno se obvezala da svoj pravni poredak usuglasi sa standardima i praksom te ustanove. U članu II/1 Ustava BiH određeno je da će se u BiH i oba entiteta osigurati najviša razina međunarodno priznatih ljudskih prava i osnovnih sloboda. Što se tiče međunarodnih standarda, u čl. II/2 određeno je da će se prava i slobode navedeni u EKLJP i njezinim protokolima primjenjivati izravno u $\mathrm{BiH}$. Oni će imati prioritet nad svim drugim zakonima. ${ }^{3}$

Jedno od najznačajnijih jamstava koje jamči EKLJP jeste pravo na pravično (pošteno) suđenje (fair trial). Budući da su povrede prava na pravično suđenje najčešći uzrok pokretanja postupaka pred ESLJP, razvijena je opsežna sudska praksa u tumačenju ovog prava. Sud je u predmetu Delcourt protiv Belgije (1970.), dao sljedeću smjernicu: „U demokratskom društvu u smislu EKLJP, pravo na pravično suđenje zauzima toliko važno mjesto da usko tumačenje članka 6. (1.) ne bi bilo u skladu s ciljem i svrhom ove odredbe. " ${ }^{4}$ Pravo na pravično suđenje u praksi ESLJP razvijalo se i širilo postupno sukladno doktrini da je EKLJP živući organizam (living instrument) i ovisi o sudskoj praksi ESLJP. Europski sud je već u predmetu Tyrer protiv Ujedinjenog Kraljevstva ${ }^{5}$ naveo da je EKLJP "živi instrument koji (...) se mora tumačiti u svjetlu uvjeta današnjice”. Stoga primjena EKLJP povlači i primjenu sudske prakse ESLJP na koji način dolazi do usvajanja

$1 \quad$ Vidi Omajec, J., Konvencija za zaštitu ljudskih prava i temeljnih sloboda u praksi Europskog suda za ljudska prava, Strasbourški acquis, Drugo dopunjeno izdanje, Novi informator, Zagreb, 2014., str. 14 .

2 O razlozima donošenja Konvencije vidi Overy, C., White, R. C. A., Context, Background and Institutions, The European Convention on Human Rights, Oxford, Oxford University Press, 2006., str. 1. - 17.

3 Podrobnije o tome kod Miljko, Z., Perspektive za implementaciju Daytonskog sporazuma s obzirom na ljudska prava, „Zbornik radova Pravnog fakulteta Sveučilišta u Mostaru, br. XI, Mostar, 1998., str. 191.

4 Presuda od 17. siječnja 1970., A. 11, str. 15. Tako i u presudi od 26. listopada 1984., De Cubber, A. 86, str. 16. Podatak kod P. van Dijak, G. J. H., van Hof, Teorija i praksa Evropske konvencije o ljudskim pravima, Muller, Sarajevo, str. 366.

$5 \quad$ Tyrer v. the United Kingdom, presuda, br. 5856/72, od 25. travnja 1978. 
KEVO, M., Pravo na neovisan i nepristran sud prema članku 6. europske konvencije za zaštitu ljudskih prava...

Zbornik radova Pravnog fakulteta Sveučilišta u Mostaru, br. XXVIII., 2020., str. 86. - 105.

novih pravila koja odgovaraju novonastalim potrebama.

U čl. 6. EKLJP sadržane su dvije skupine prava. Za razliku od st. 2. i 3. članka 6. koji sadrži posebne odredbe koje navode dodatne procesne norme koje se primjenjuju samo na one koje se tereti za kazneno djelo, u prvoj skupini su zajednički temelji primjenjivi i za svaki postupak koji se tiče utvrđivanja građanskih prava i obveza.

Dakle, u prvoj skupini su definirana načela sudskog postupka uopće. Prava zajednička građanskim i kaznenim postupcima mogu se razvrstati u tri značajne cjeline, a to su pravo na pristup sudu, pravo na postupak odgovarajuće kvalitete i pravo na zakonom ustanovljeni, neovisan i nepristran sud. ${ }^{6}$

6 Pravo neovisnosti sudovanja uređeno je i brojnim drugim međunarodnim dokumentima. Tako Opća deklaracija o pravima čovjeka propisuje da svatko ima potpuno jednako pravo na pravično i javno suđenje pred nezavisnim i nepristranim sudom koji će odlučivati o njegovim pravima i obvezama i osnovanosti svake krivične optužbe protiv njega. Vidi čl. 10. Opće deklaracije o pravima čovjeka, „Službeni list SFRJ,“ br. 7/1971.

Međunarodni pakt o građanskim i političkim pravima propisuje da su svi jednaki pred sudovima. Svatko ima pravo da zakonom određeni nadležni, nezavisni i nepristrani sud nepristrano i javno ispita njegov predmet i odluči o osnovanosti svake kaznene optužbe koja je protiv njega podignuta ili spora o građanskopravnim pravima i obvezama..." Vidi čl. 14. st. 1. Međunarodnog pakta o građanskim i političkim pravima, „Službeni list SFRJ," br. $71 / 1976$.

Povelja o temeljnim pravima Europske unije propisuje da svatko, čija su prava i slobode, zajamčene pravom Unije, prekršeni, ima pravo na učinkovit pravni lijek pred sudom, u skladu s uvjetima utvrđenim ovim člankom. Svatko ima pravo na pravično javno suđenje, u razumnom vremenskom roku pred neovisnim i nepristranim sudom, prethodno osnovanim u skladu sa zakonom. Svatko ima mogućnost da bude savjetovan, branjen i zastupan. Vidi čl. 47. st. 1. i 2. Povelje o temeljnim pravima Europske unije, „Službeni list Europske unije, " br. C 202/389, dostupno na: https://eur-lex.europa.eu/legal-content/HR/ TXT/PDF/?uri=CELEX:12016P/TXT\&from=FR

Osnovna načela Ujedinjenih nacija o neovisnosti pravosuđa (dalje - Osnovna načela UN) definiraju zahtjeve neovisnosti pravosuđa već u prvom načelu: „Nezavisnost sudstva je zajamčena od države i zaštićena Ustavom i nacionalnim zakonima. Dužnost je svih ustanova, vladinih i drugih, da poštuju nezavisnost sudstva." Osnovna načela Ujedinjenih nacija o neovisnosti pravosuđa (Basic Principles on the Independence of the Judiciary) usvojena su na Sedmom kongresu Ujedinjenih nacija za sprječavanje zločina i postupanja prema prestupnicima, održanog u Milanu od 26. kolovoza do 6. rujna 1985. godine i potvrđena od Generalne skupštine u njezinim rezolucijama 40/32 od 29. studenog 1985. godine i 40/146 od 13. prosinca 1985. godine, dostupno na: https:/www.ohchr.org/EN/UDHR/ Pages/UDHRIndex.aspx

Preporuka CM/Rec (2010) 12 Vijeća ministara državama članicama o neovisnosti, efikasnosti i ulozi sudaca na isti način (dalje - Preporuka CM/Rec (2010) 12) kao i UN Osnovna načela o neovisnosti sudstva govori o neprimjerenim utjecajima koji mogu ugrožavati neovisnost pravosuđa, ne precizirajući ih, ali navodi i mjere zaštite, poput stalnosti sudačke 
Neovisnost i nepristranost, iako su u uskoj vezi, predstavljaju dva različita koncepta, od kojih svaki ima posebno značenje. Pojam neovisnost odnosi se na suce i tijela vlasti, te podrazumijeva autonomiju određenog suca da bez vanjskih utjecaja riješi određeni slučaj, primjenom zakona na utvrđene činjenice. Pojam nepristranost odražava odnos suca prema konkretnom slučaju i njegovim sudionicima (strankama).

ESLJP je utvrdio da su koncepti neovisnosti i nepristranosti zakonito osnovanog suda usko povezani, radi čega ove dvije pretpostavke obično razmatra zajedno.

ESLJP je kroz svoju praksu utvrdio opće kriterije neovisnosti, ističući da se posebna pažnja treba obratiti na: način izbora sudaca, trajanje njihovih mandata, postojanje jamstava za zaštitu od vanjskih pritisaka, kao i na pitanje ostavlja li domaći sud dojam neovisnosti.

\section{Pojam "zakonom ustanovljeni sud" prema autonomnom tumačenju ESLJP}

Član 6. stavak 1. EKLJP određuje da svatko ima pravo da zakonom ustanovljeni neovisni i nepristrani sud ispita njegov slučaj. To znači da pravosudni sustav treba biti uspostavljen i reguliran zakonima, jer inače ne bi imao legitimitet koji je u demokratskom društvu potreban za postupanje u pojedinim predmetima. ${ }^{7}$ Ovakav pravni okvir nužan je da bi se osiguralo da organizacija sudstva u demokratskom društvu ne bude prepuštena diskreciji izvršne vlasti, već ono treba biti regulirano zakonima koje donosi parlament. ${ }^{8}$ Izraz "ustanovljen zakonom" ne

funkcije, financijske neovisnosti, neophodnosti postojanja apsolutne nadležnosti sudova, izuzeća sudaca i odgovarajućeg načina za preispitivanje sudskih odluka. Vidi Preporuka $\mathrm{CM} / \operatorname{Rec}$ (2010) Vijeća ministara državama članicama o sucima: neovisnost, djelotvornost i odgovornosti (Recommendation CM/Rec (2010) 12 of the Committee of Ministers to member states on judges: independence, efficiency and responsibilities) usvojena od Vijeća ministara 17. studenog 2010. godine na 1098. sastanku zamjenika ministara, dostupno na: https://rm.coe.int/16807096c1

Europska povelja o statutu za suce utvrđuje da se načela u vezi sa sucima, gdje spada i neovisnost pravosuđa, uređuju na najvišem nivou u državi, odnosno ustavom, a zakonske odredbe ne smiju umanjiti povjerenje u nezavisno i nepristrano sudstvo. Vidi čl. 1. t. 1.1. Europske povelje o statutu za suce (dalje - Europska povelja o statutu za suce), dostupno na: http://www.uhs.hr/old/data_sve/linkovi_i_tekst_dokumenti_povelja.htm

$7 \quad$ Lavents v. Latvia, presuda, br. 58442/00, od 28. studenog 2002.

8 Coëme and Others v. Belgium, presuda, br. 32492/96, 32547/96, 32548/96, 33209/96 i 33210/96, od 22. lipnja 2000., Zand v. Austria, br. 7360/76, Izvješće Europske 
obuhvaća samo pravni temelj za samo postojanje suda već znači i to da sud mora poštovati konkretna pravila koja ga uređuju. ${ }^{9}$ Prema općem načelu, prvenstveno je na nacionalnim sudovima da tumače odredbe nacionalnog prava, dok je uloga ESLJP u tom smislu ograničena. ${ }^{10} \mathrm{U}$ tom smislu neovisno o tome kako nacionalno pravo uređuje način osnivanja suda, ESLJP ispituje i utvrđuje jedino to je li domaći sud bio osnovan sukladno tim zakonskim odredbama.

Prema praksi ESLJP, pojam sud/tribunal, u materijalnom smislu te riječi, određen je njegovom pravosudnom funkcijom, što znači da on odlučuje o predmetu u okviru svoje nadležnosti na temelju vladavine prava i nakon postupka provedenog na propisan način. ${ }^{11}$ Nadalje pojam suda/tribunala mora ispunjavati i uvjete poput neovisnosti od izvršne vlasti i stranaka u postupku, trajanje sudačkih mandata, postojanje postupovnih jamstava, od kojih se nekoliko nalazi u samom čl. 6. stav 1. EKLJP. ${ }^{12}$ Po pitanju sastava suda, ESLJP je utvrdio da sud može biti sastavljen i od osoba koje nisu profesionalni suci. ${ }^{13}$ Ono što je bitno obilježje suda jeste njegova nadležnost u donošenju pravno obvezujućih odluka. ${ }^{14}$ Jedan od temeljnih aspekata vladavine prava je načelo pravne sigurnosti koje zahtijeva da kad su sudovi pravomoćno odlučili o nekom pitanju, njihova odluka ne bi trebala biti dovedena u pitanje. ${ }^{15}$

Brojna su tijela koja se prema nacionalnom pravu neće smatrati sudom, ali hoće prema čl. 6. EKLJP sukladno autonomnom tumačenju pojma suda od ESLJP. Pravo na pristup pravosuđu pretpostavlja da tijelo kojem je pristup osiguran ima u državi kojoj pripada svojstvo suda/tribunala u smislu čl. 6. stav 1. EKLJP. To znači da je takvo tijelo neovisan i nepristran sud ustanovljen zakonom. Nije dakle odlučno naziva li se to tijelo sud ili drugačije. ${ }^{16}$ Zaključuje se da je pojam

komisije od 12. listopada 1978.

9 Okurenko and Strygun v. Ukraine, presuda, br. 29458/04 i 29465/04, od 20. srpnja 2006.

10 Bugajny and Others v. Poland, presuda, br. 22531/05, 6. studeni 2007., Richert v. Poland, presuda, br. 54809/07, od 25. listopada 2011.

$11 \quad$ Cyprus v. Turkey, presuda, br. 25871/94, od 10. svibnja 2001.

12 Le Compte, Van Leuven and De Meyere v. Belgium, presuda, br. 6878/75; 7238/75, od 23. lipnja 1981., Cyprus v. Turkey, presuda, br. 25871/94, od 10. svibnja 2001. Ettl v. Austria, presuda, br. 9273/79, od 23. travnja 1987. godine.

Tako je u predmetu Van de Hurk protiv Nizozemske ESLJP naveo: $\bigotimes($...) Prema mišljenju Suda ovlast donošenja obvezujuće odluke koju ne može izmijeniti tijelo koje nije pravosudno na štetu pojedine stranke svojstvena je samom pojmu „sud“. Vidi Van de Hurk v. the Netherlands, presuda, br. 16034/90, od 19. travnja 1994.

15 Brumărescu v. Romania, presuda, br. 28342/95, od 28. listopada 1999.

Vidi Grbić, S. Pošteno suđenje u građanskim postupcima u Hrvatskoj u svjetlu članka 6., 
zakonito osnovanog suda, koji se štiti čl. 6. stav 1. EKLJP širi od pojma koje mu daje nacionalno pravo, i da mu je i značenje autonomno.

\section{Neovisnost suda}

\subsection{Opća razmatranja}

Načelo neovisnosti sudstva izvedeno je iz osnovnog načela vladavine prava, posebice iz načela diobe vlasti. Prema načelu diobe vlasti, izvršna, zakonodavna i sudska vlast predstavljaju tri odvojene i međusobno neovisne grane vlasti. Ta međusobna neovisnost različitih dijelova državne vlasti znači da nisu dopuštene situacije prema kojima jedna vlast zadire u nadležnost i prerogative drugih vlasti. ${ }^{17}$ ESLJP je više puta ustvrdio kako je poštivanje načela diobe vlasti ključno načelo efikasne demokracije koje se ne može dovoditi u sumnju. ${ }^{18}$

Isto tako ESLJP je utvrdio da su koncepti neovisnosti i nepristranosti zakonito osnovanog suda usko povezani, te ih je teško razdvojiti, posebice kada su argumenti podnositelja predstavke, koji $\mathrm{u}$ isto vrijeme dovode $\mathrm{u}$ pitanje i neovisnost $\mathrm{i}$ nepristranost nacionalnog suda i njegovo zakonito osnivanje, temeljeni na istim činjenicama. Iz ovog razloga ESLJP obično razmatra obje te pretpostavke zajedno. ${ }^{19}$

Nadalje ESLJP je dosljedno naglasio da opseg obveze koju ima država da osigura suđenje pred "neovisnim i nepristranim sudom" na temelju članka 6. stavka 1. EKLJP nije ograničen na sudstvo. Ta obveza podrazumijeva i obveze izvršne, zakonodavne i svake druge državne vlasti, bez obzira na njezinu razinu, da poštuje i pridržava se presuda i odluka sudova, čak i kada se s njima ne slažu. Stoga država mora poštovati autoritet sudova jer je to nužan preduvjet za povjerenje koje javnost ima u sudove i, u širem smislu, u vladavinu prava. Da bi to bilo tako, ustavna jamstva neovisnosti i nepristranosti sudstva nisu dovoljna. Ona moraju biti učinkovito uklopljena u svakodnevne upravne stavove i prakse. ${ }^{20}$

stavka 1. Europske konvencije o ljudskim pravima (poštenost - razumna duljina trajanja postupaka - nezavisnost i nepristranost sudova i sudaca - pristup sudu - jednakost oružja), Pravni fakultet Sveučilišta u Rijeci, 2014., str. 29. - 32.

Vidi Bužanin, O., Lalović, Lj., MODUL 1, Nosioci pravosudnih funkcija i društvo, (dalje BUŽANIN - LALOVIĆ), Sarajevo, 2010., str. 13., dostupno na: https://www.pravosudje.ba Chevrol v. France, presuda, br. 49639/99, od 13. veljače 2003. 
Prema praksi ESLJP-a, izraz "neovisan" odnosi se na neovisnost od ostalih grana vlasti (izvršne i parlamenta), ${ }^{21}$ te također od stranaka. ${ }^{22}$ Tako će neovisnost sudaca biti narušena ako se izvršna vlast umiješa u predmet koji se vodi pred sudom s ciljem utjecaja na ishod postupka. Stoga je utvrđena povreda u predmetu Sovtransavto Holding protiv Ukrajine ${ }^{23}$ kada je predsjednik Ukrajine tražio pismenim putem od Vrhovnog arbitražnog tribunala da „zaštiti interese državljana Ukrajine" u odnosu na rusku tvrtku podnositeljicu zahtjeva. ${ }^{24} \mathrm{U}$ predmetu Sramek protiv Austije, ${ }^{25}$ gdje je jedan od članova Suda osoba koja je hijerarhijski podređena jednoj od strana u sporu, ESLJP je utvrdio da strane u sporu mogu imati opravdanu dvojbu o neovisnosti te osobe. Takva situacija ozbiljno utječe na povjerenje koje sudovi moraju poticati u demokratskom društvu.

\subsection{Kriteriji za procjenu neovisnosti}

Pri utvrđivanju može li se neko tijelo smatrati neovisnim, konkretno od izvršne vlasti i stranaka u postupku, ESLJP je uzimao u obzir kriterije poput načina izbora sudaca, trajanje njihovih mandata, postojanje jamstva za zaštitu od vanjskih pritisaka, te ostavlja li domaći sud dojam neovisnosti. ${ }^{26}$

\subsubsection{Način imenovanja sudaca}

Jedan od kriterija koji ESLJP primjenjuje prilikom ispitivanja neovisnosti domaćeg suda jeste i način imenovanja i razrješenja sudaca. Kada ESLJP ispituje je li došlo do povrede neovisnosti zbog načina na koji su imenovani suci, onda činjenica da imenovanje sudaca od izvršne ili zakonodavne vlasti sama po sebi ne predstavlja povredu, pod uvjetom da su imenovani slobodni od utjecaja ili pritisaka prilikom vršenja svojih pravosudnih uloga. ${ }^{27}$ Dakle, prilikom obrazovanja pravosudnog sustava, države potpisnice EKLJP uživaju određenu slobodu. Da bi

$21 \quad$ Beaumartin v. France, presuda, br. 15287/89, od 24. studenog 1994.

22 Sramek v. Austria, presuda, br. 8790/79, od 22. listopada 1989.

23 Sovtransavto Holding v. Ukraine, presuda, br. 48553/99, od 25. srpnja 2002.

Vidi Gomien, D., Priručnik, Europska konvenciju o ljudskim pravima, Zadar, 2007., str. 91. -92.

Sramek v. Austria, bilj. 21.

Langborger v. Sweden, presuda, br. 11179/84, od 22. lipnja 1989., Kleyn and Others $v$. the Netherlands, presuda, br. 39343/98, 39651/98, 43147/98 i 46664/99, od 6. svibnja 2003. 
neovisnost suca bila ugrožena, zbog načina na koji se oni izabiru, potrebno je da podnositelj predstavke dokaže da je ona bila ugrožena načinom uspostavljanja sudstva u cjelini ili konkretnog suda, odnosno konkretnog postupajućeg suca, što je utjecalo na ishod samog postupka. ${ }^{28}$

\subsubsection{Trajanje sudačkih mandata}

ESLJP nije odredio neko konkretno trajanje mandata već ovo pitanje razmatra ovisno o okolnostima svakog pojedinačnog predmeta koji raspravlja. U predmetu Maktouf i Damjanović protiv Bosne i Hercegovine ESLJP je utvrdio da je dvogodišnji mandat međunarodnih sudaca, koji su sudili u vijeću za ratne zločine pred Sudom Bosne i Hercegovine, ipak predstavljao jamstvo neovisnosti. Iako je njihov mandat bio relativno kratak, Sud je našao da je to razumljivo s obzirom na privremenu prirodu međunarodnog prisustva na Sudu Bosne i Hercegovine i mehanizme međunarodne razmjene stručnjaka. U predmetu Campbell i Fell protiv Ujedinjenog Kraljevstva ${ }^{29}$ ESLJP je odlučivao o neovisnosti zatvorskog odbora koji se birao na tri godine. Iako se razdoblje od tri godine smatralo relativno kratkim, ESLJP je uzeo u obzir činjenicu da je to neplaćeni posao i da je teško doći do volontera koji bi ga obavljali, radi čega je prihvatio da je to razdoblje ipak bilo dovoljno za osiguranje neovisnosti njegovih članova pa nije došlo do povrede čl. 6. stav 1. EKLJP. Po pitanju pitanja stalnosti sudačke funkcije, stav ESLJP je da suci mogu biti imenovani na mandat ograničenog trajanja, dakle nije potrebno da budu imenovani doživotno, pod uvjetom da ih vlasti ne mogu otpuštati svojevoljno ili na neprimjerenoj osnovi. ${ }^{30}$ Zaključuje se da dužina trajanja mandata sudaca neće biti ključna za ocjenu neovisnosti suda, ali je od izuzetnog značaja da se za vrijeme trajanja tog mandata poštuje stalnost sudačke funkcije. U svakom slučaju, što je mandat duži, to su veći izgledi da neće postojati povrede čl. 6. stav 1. EKLJP.

\subsubsection{Jamstva protiv vanjskog pritiska}

Jamstva protiv vanjskih pritisaka na sudstvo prvenstveno se vežu uz načelo trodiobe vlasti, te pritiske i neprimjerene utjecaje izvršne i zakonodavne vlasti na sudske vlast. U tom smislu ESLJP stavlja težište na utjecaj, posebno izvršne vlasti,

$28 \quad$ Zand v. Austria, bilj. 7.

29 Campbell and Fell v. The United Kingdom, presuda, br. 7819/77, 7878/77, od 28. lipnja 1984.

$30 \quad$ Vidi P. van Dijak, G. J. H. Van Hoof, o. c., str. 424. 
kako na sudstvo u cjelini, tako i na svakog njegovog pojedinog člana. U predmetu Beaumartin protiv Francuske ESLJP je utvrdio da samo tijelo koje ima punu nadležnost i zadovoljava mnogobrojne zahtjeve, između kojih je i zahtjev neovisnosti od izvršne vlasti, a i neovisnost od stranaka u postupku, može se nazvati sudom u smislu čl. 6. stav 1. EKLJP. ${ }^{31,32}$

Sudačka neovisnost, također, zahtijeva da nijedan sudac ne bude izložen neprimjerenim utjecajima koji dolaze, ne samo izvan pravosuđa, već i iznutra. Ta unutarnja sudačka neovisnost zahtjeva da suci ne budu izloženi uputama i pritiscima drugih sudaca ili osoba koje imaju upravne odgovornosti na sudu, poput predsjednika suda ili predsjednika sudskog odjela. ${ }^{33}$ Ako nema dostatne zaštite koja osigurava neovisnost sudaca unutar pravosudnoga sustava, a osobito u odnosu na njihove nadređene u pravosudnim tijelima, Sud bi to moglo navesti na zaključak da su sumnje podnositelja zahtjeva glede (neovisnosti i) nepristranosti suda možda bile objektivno opravdane. ${ }^{34}$

\subsubsection{Dojam neovisnosti}

Dojam također može biti važan za utvrđivanje može li se sud smatrati neovisnim. ESLJP je u predmetu Sacilor Lormines protiv Francuske u pogledu neovisnosti utvrdio da je stajalište stranke važno, no ne i odlučujuće; ono što jest odlučujuće je može li se strah te stranke smatrati „objektivno opravdanim." ${ }^{35}$ Stoga nema problema u pogledu neovisnosti kad ESLJP smatra da "objektivni promatrač" ne bi imao razloga za takvu zabrinutost u okolnostima tog predmeta. ${ }^{36}$

Beaumartin v. France, presuda, br. 15287/89, stav 38, od 24. studenog 1994.

Prema Preporuci CM/Rec (2010) 12 Vijeća ministara državama članicama o sucima, nitko osim nadležnog suda ne bi trebao da preispituje odluke sudaca, niti da svojim komentarima podriva neovisnost sudstva ili povjerenje javnosti u njega, pri čemu suci nemaju obvezu da opravdaju svoje odluke izvan teksta svojih odluka. Poglavlje II, Preporuke CM/ $\operatorname{Rec}(2010) 12$.

Bangalorski principi sudačkog ponašanja (The Bangalore Draft Code of Judicial Conduct) 2002, (dalje -Bangalorski principi) u okviru ostvarivanja sudačke neovisnosti, navode da je neophodna i neovisnost od kolega sudaca u pogledu donošenja odluka, te da suci ne bi trebali trpjeti pritiske ni predsjednika suda, ni drugih sudaca, niti više instance, dostupno na: https://www.unodc.org/res/ji/import/international_standards/commentary_on_the_ bangalore_principles_of_judicial_conduct/bangalore_principles_ 


\section{Nepristranost suda}

Pravo na pravično suđenje zahtijeva da sudac bude nepristran. Nepristranost zahtijeva da sudac nije opterećen predrasudama u vezi s odlukom koju donosi, da ne dopusti da prilikom suđenja bude opterećen vanjskim informacijama (bilo da se radi o stavu javnosti ili bilo kojem drugom pritisku), već da svoje mišljenje zasniva na onim činjenicama iznesenim na suđenju. Pravo na suđenje pred nepristranim sudom znači da sudac nema poseban interes u određenom slučaju, kao i da nema već formirano mišljenje o postupku ili strankama. ${ }^{37,38}$

\subsection{Kriteriji za ocjenu nepristranosti}

ESLJP kroz svoju praksu tumači pojam nepristranosti kao odsustvo predrasuda ili pristranosti u postupku. Kod utvrđivanja pojma nepristranosti, ključan je odnos suda prema strankama, pa je ESLJP u predmetu Hauschildt protiv Danske ${ }^{39}$ postavio dva kriterija, prema kojima procjenjuje je li došlo do povrede nepristranosti: "Postojanje nepristranosti u smislu čl. 6. stav 1. mora biti utvrđeno prema subjektivnom kriteriju, što znači na temelju osobnog uvjerenja suca koji odlučuje o predmetu, a također i na temelju objektivnog kriterija kojim se isključuje postojanje bilo kakve opravdane sumnje u njegovo takvo odlučivanje."

\subsubsection{Subjektivni kriterij}

Kod primjene subjektivnog kriterija ESLJP je zauzeo stav da se mora pretpostaviti osobna nepristranost suca dok se ne dokaže suprotno. ${ }^{40} \mathrm{Da}$ bi se dokazala subjektivna nepristranost, ESLJP zahtjeva dokaze konkretne pristranosti, primjerice da se ustanovi je li sudac pokazao neprijateljski stav. ${ }^{41}$ Neće se smatrati dovoljnim dokazom koji potkrepljuje tvrdnje o subjektivnoj nepristranosti suca činjenica da se sudac nije izuzeo iz sudjelovanja u parničnom žalbenom postupku

37 Vidi BUŽANIN - LALOVIĆ, o. c., str. 16.

38 Prema Preporuci CM /Rec (2010) 12, državama se savjetuje način raspodjele predmeta, jasni razlozi i načini izuzeća sudaca, među kojima se pojavljuju i oni koji ugrožavaju sudačku nepristranost.

Hauschildt v Denmark, presuda, br. 10486/83, od 24. svibnja 1989. Vidi i Micallef v Malta, presuda, br. 17056/06, od 15. listopada 2009.

$40 \quad$ La Compte, Van Leuven i De Meyere v Belgium, bilj. 11.

$41 \quad$ Buscemi v Italy, presuda, br. 29569/95, od 16. rujna 1999. 
nakon svog ranijeg sudjelovanja u drugom povezanom građanskom postupku. ${ }^{42}$ Ovo je vrlo snažna pretpostavka koju je u praksi jako teško dokazati, a procjenjuje se u svakom konkretnom slučaju, jer je teško ustanoviti pravilo putem kojeg bi se unaprijed moglo utvrditi radi li se o nepristranosti domaćeg suda.

\subsubsection{Objektivni kriterij}

Kod objektivnog kriterija potrebno je ustanoviti postoji li sumnja je li određenom sucu ili tijelu koje zasjeda kao sud, sasvim odvojeno od osobnog ponašanja jednog suca, nedostaje nepristranost. To podrazumijeva da je stajalište onih, koji tvrde da nepristranost ne postoji, važno ali ne i odlučujuće za odluku postoji li u određenom predmetu legitiman razlog za strah da određeni sudac ${ }^{43}$ ili tijelo koje zasjeda kao sud ${ }^{44}$ nije nepristrano. Odlučujuće je može li se taj strah smatrati objektivno opravdanim. ${ }^{45}$ Ovdje je u pitanju povjerenje koje sudovi u demokratskom društvu moraju ulijevati u javnosti. Dakle, svaki sudac za kojeg postoji opravdan strah da nije nepristran mora se izuzeti. ${ }^{46}$ Kako bi sudovi u javnosti poticali povjerenje koje je prijeko potrebno, treba uzeti u obzir i pitanja vezana uz unutrašnju organizaciju. Postojanje nacionalnih postupaka za osiguranje nepristranosti, posebice pravila koja uređuju izuzeće sudaca, značajan je čimbenik. Takva pravila pokazuju želju nacionalnog zakonodavca da se uklone sve razumne dvojbe glede nepristranosti dotičnoga suca ili suda i predstavljaju pokušaj osiguranja nepristranosti uklanjanjem tih uzroka zabrinutosti. Uz osiguranje nepostojanja stvarne pristranosti, usmjerena su i na otklanjanje svega onoga što bi moglo izgledati kao pristranost, te tako služe za promicanje povjerenja koje sudovi moraju nadahnjivati u javnosti u demokratskom društvu. ${ }^{47}$ ESLJP takva pravila uzima u obzir kad donosi svoju procjenu je li sud bio pristran i, osobito, mogu li se strahovi podnositelja zahtjeva smatrati objektivno opravdanima.

Objektivni kriteriji se uglavnom odnose na situacije kad ista osoba obnaša različite funkcije unutar sudskog postupka ili kad ima hijerarhijske ili druge veze s drugom osobom koja sudjeluje u postupku. Ovdje spadaju obnašanje različitih sudbenih funkcija, obnašanje i savjetodavnih i sudbenih funkcija u istom pred-

\footnotetext{
42 Golubović v Croatia, presuda, br. 43947/10, od 27. studenog 2012.

$43 \quad$ Morel v France, presuda, br. 34130/96, od 6. lipnja 2000.

Luka v Romania, presuda, br. 34197/02, od 21. srpnja 2009.

47 Mežnarić v Croatia, presuda br. 71615/01 od 33. studenog 2005.
} 
metu, obnašanje i sudbenih i izvansudbenih funkcija u istom predmetu. ESLJP pitanje obnašanja različitih sudbenih funkcija, odnosno ocjenu je li sudjelovanje istog suca u različitim fazama postupka, sukladno zahtjevu nepristranosti propisanim čl. 6. stavak 1. EKLJP, promatra od predmeta do predmeta uzimajući u obzir okolnosti svakog pojedinačnog slučaja. Kod obnašanja različitih sudbenih funkcija prvotno se radilo o kaznenim postupcima, ali je ESLJP kroz svoju praksu te kriterije protegnuo i na građanske postupke.

U predmetu Piersack protiv Belgije ${ }^{48}$ ESLJP je utvrdio da je došlo do povrede čl. 6. stavak 1. EKLJP jer je sudac koji je sudio u postupku protiv podnositelja prije toga bio član odjela koji je proveo istragu u tom predmetu te podnio tužbu protiv njega. ESLJP je smatrao da to što je sudac nekoć bio zaposlen u državnom odvjetništvu nije razlog za strah da nije nepristran. Ipak, ako pojedinac, nakon što je u tom odjelu obnašao dužnost čija je priroda takva da je u sklopu svojih dužnosti možda morao raditi na istoj stvari, nakon toga zasjeda u istom predmetu kao sudac, javnost ima pravo na strah da on ne nudi dovoljna jamstva nepristranosti. Stoga je zaključio da nije zadovoljen zahtjev nepristranosti jer sastav suda koji je trebao odlučiti o optužbi ide u prilog tužiteljstvu.

Isto tako u predmetu De Cubber protiv Belgije ${ }^{49}$ ESLJP je naveo da je situacija, kad je ista osoba u istom predmetu uzastopno obnašala dužnosti suca istrage i raspravnog suca, također navela Sud na utvrđenje da se nepristranost prvostupanjskog suda podnositelju zahtjeva može činiti podložna dvojbi.

Međutim u predmetu Bulut protiv Austrije, ${ }^{50}$ ESLJP je utvrdio da, kad je sudjelovanje raspravnog suca $\mathrm{u}$ istrazi bilo vremenski ograničeno i sastojalo se od ispitivanja dva svjedoka te nije uključivalo nikakvo ocjenjivanje dokaza niti zahtijevalo donošenje zaključka, kako se strah podnositelja zahtjeva da nadležni nacionalni sud nije nepristran ne može smatrati objektivno opravdanom.

I u građanskim postupcima ESLJP ocjenu je li sudjelovanje istog suca u različitim fazama postupka, sukladno zahtjevu nepristranosti propisanim čl. 6. stavak 1 . EKLJP, promatra prema okolnostima svakog pojedinačnog slučaja.

Tako je u predmetu Morel protiv Francuske ${ }^{51}$ ESLJP smatrao da nije došlo do povrede čl. 6. stavak 1. EKLJP zbog činjenice da je sudac već donosio odluke prije suđenja, odnosno da se ova činjenica ne može sama po sebi smatrati opravdavanjem za zabrinutost u vezi njegove nepristranost. Ono što je bitno jest opseg i priroda mjera koje je sudac poduzeo prije suđenja. Isto tako, činjenica da sudac

$48 \quad$ Piersack v. Belgium, presuda, br. 8692/79, od 1. listopada 1982.

50 Bulut v. Austria, presuda, br. 17358/90, od 22. veljače 1996.

$51 \quad$ Morel v. France, presuda, br. 34130/96, od 6. lipnja 2000. 
detaljno poznaje spis predmeta ne podrazumijeva nikakve predrasude s njegove strane koje bi spriječile da ga se smatra nepristranim pri donošenju odluke o osnovanosti. Niti preliminarna analiza dostupnih informacija ne znači da je konačna analiza prejudicirana. Ono što jest bitno je da ta analiza bude provedena kad je presuda donesena te da bude utemeljena na izvedenim dokazima i tvrdnjama iznesenim na suđenju.

S druge strane, ESLJP je u predmetu Driza protiv Albanije ${ }^{52}$ utvrdio povredu načela nepristranosti u smislu čl. 6. stavak 1. EKLJP u kojem su neki suci koji su već odlučivali o predmetu trebali odlučiti jesu li pogriješili u svojoj ranijoj odluci i u kojem su druga tri suca već izrekla svoje mišljenje o toj stvari.

Zaključuje se da sama činjenica da je sudac prethodno imao veze s podnositeljem predstavke kroz različite funkcije unutar sudskog postupka ne predstavlja automatski povredu čl. 6. stavak 1. EKLJP. Potrebne su posebne pretpostavke koje sud ispituje od predmeta do predmeta uzimajući u obzir okolnosti svakog pojedinačnog slučaja.

\section{Pravo na neovisan i nepristran sud u zakonodavstvu Bosne i Hercegovine}

\subsection{Uspostava neovisnog sudstva}

Nakon osamostaljenja Bosna i Hercegovina je naslijedila pravni sustav u kojem je bilo dominantno načelo jedinstva vlasti. Sve do 2002. godine neovisnost sudske vlasti nije bila jasno definirana u ustavima jer Ustav Bosne i Hercegovine, odnosno Aneks 4 Daytonskog mirovnog sporazuma ne sadrži odredbu koja jamči podjelu vlasti na zakonodavnu, izvršnu i sudsku, a niti su pravna pravila kojima su bila regulirana imenovanja sudaca bila u skladu s europskim standardima. Uspostava istinski neovisnog i nepristranog sudstva u $\mathrm{BiH}$ identificirana je od Vijeća za implementaciju mira kao pitanje od posebne važnosti za vladavinu zakona i pomirenje u $\mathrm{BiH}$. Da bi se osigurao takav pravosudni sustav, koji će osigurati vladavinu zakona, visoki predstavnik je dana 23. svibnja 2002. godine donio dvije odluke kojima je proglasio amandmane na entitetske ustave, a nakon toga je proglasio tri zakona o Visokim sudbenim i tužiteljskim vijećima. Zajednička karakteristika ovim amandmanima je da se u preambulama, koje su bile temelj za donošenje amandmana na entitetske ustave, visoki predstavnik poziva na europske standarde $\mathrm{u}$ pogledu neovisnosti sudske vlasti. ${ }^{53} \mathrm{Na}$ ovaj način su i

$52 \quad$ Driza v. Albania, presuda, br. 33771/02, od 13. studenog 2007. međunarodni standardi sadržani u 'Osnovnim principima neovisnosti sudstva' UN-a iz 
u bosanskohercegovačkom zakonodavstvu ispoštovana jamstva koja su postavljena međunarodnim dokumentima s ciljem zaštite neovisnosti i nepristranosti zakonito osnovanog suda, kao i u pogledu tijela koje će vršiti imenovanje sudaca.

U odnosu na Federaciju Bosnu i Hercegovinu (u daljnjem tekstu - FBiH) amandmanima na Ustav u čl. 4. st. 3. Ustava Federacije Bosne i Hercegovine (u daljnjem tekstu - Ustav FBiH) je propisano da je sudska vlast samostalna i neovisna od izvršne i zakonodavne vlasti u $\mathrm{FBiH}$, a u st. 4. istog člana da Visoko sudbeno i tužiteljsko vijeće $\mathrm{FBiH}$ osigurava samostalnost, neovisnost i nepristranost, stručnost i efikasnost sudstva i tužiteljske funkcije u FBiH. Nadležnosti Visokog sudbenog i tužiteljskog vijeća, između ostalog, uključuju imenovanje, vođenje disciplinskog postupka i smjenjivanje sudaca, osim sudaca Ustavnog suda Federacije, i obuhvaćaju i tužitelje, glavne tužitelje i zamjenike tužitelja u Federaciji $\mathrm{BiH} .{ }^{54}$ Osim ovoga, kao dopuna ove nadležnosti, čl. 6. st 1. je propisano suce Vrhovnog suda, uključujući i predsjednika Suda, bira, imenuje, provodi disciplinski postupak protiv i smjenjuje Visoko sudbeno i tužiteljsko vijeće u skladu sa zakonom. ${ }^{55}$ Amandmanima na Ustav je također propisano da suce županijskih sudova, ${ }^{56} \mathrm{kao}$ i suce općinskih sudova, ${ }^{57}$ uključujući i predsjednike sudova, bira, imenuje, provodi disciplinski postupak protiv i smjenjuje Visoko sudbeno i tužiteljsko vijeće $\mathrm{FBiH} .^{58}$

1985. godine, Preporuci Vijeća Europe br. R 94 (12) Ministarskog Vijeća zemalja članica o 'Neovisnosti, efikasnosti i ulozi sudaca' i Europskoj Povelji Vijeća Europe o 'Statutu za suce' budu ispoštovani i da se uspostavi profesionalan, efikasan i nepristran postupak za odabir, imenovanje, disciplinski postupak i postupak razrješenja sudaca i tužitelja." Vidi Preambulu odluke visokog predstavnika o amandmanima na entitetske ustave od 23. svibnja 2002.

Ovaj član je dodan amandmanom L VII odlukom visokog predstavnika od 23. svibnja 2002. godine, objavljenoj u Službenim novinama FBiH, br. 22/02 od 5. lipnja 2002.

Amandman XLVII koji je nametnuo visoki predstavnik od 19. travnja 2002. godine, objavljen u Službenim novinama FBiH br. 16/02 od 28. travnja 2002., izbrisao je uvodnu rečenicu i točku a) koja je glasila: "Ako izričito nije drugačije utvrđeno: a) jednak je broj sudaca Hrvata i sudaca Bošnjaka u svakom sudu Federacije. Ostali će biti odgovarajuće zastupljeni u svakom takvom sudu." Prvobitne točke b) i c) postale su točke a) i b). Amandman XLVII je zamijenjen amandmanom LIX odlukom visokog predstavnika od 23. svibnja 2002. godine, objavljena u Službenim novinama FBiH, br. 22/02 od 5. lipnja 2002.

Vidi glava V. 4., čl. 11. st. 2. Ustava FBiH "Službene novine FBiH," br. 1/94, 13/97 i 22/02. Vidi glava VI. čl. 7. Ustava FBiH.

Istovjetne su odredbe u čl. 121.a st. 1. i 2. Ustava Republike Srpske dodane amandmanom XCIV odlukom visokog predstavnika od 23. svibnja, objavljenoj u Službenom glasniku RS, br. $36 / 00$. 
Amandmanima na Ustav FBiH je isto tako predviđeno da se suci Vrhovnog suda, ${ }^{59}$ županijskih sudova ${ }^{60}$ i općinskih sudova, ${ }^{61}$ osim dodatnih sudaca, imenuju na neograničen mandat, osim ako ne podnesu ostavku, ako ne budu umirovljeni ili ne budu s razlogom smijenjeni od Visokog sudbenog i tužiteljskog vijeća sukladno zakonu.

Jedinstveni Zakon o Visokom sudbenom i tužiteljskom vijeću Bosne i Hercegovine usvojen je 21. svibnja 2004. godine, a stupio je na snagu 1. lipnja 2004. godine ${ }^{62}$ Zakonom o VSTV-u BiH propisuje da je Vijeće samostalno tijelo Bosne i Hercegovine i da ima svojstvo pravne osobe. ${ }^{63}$ Vijeće kao neovisno i samostalno tijelo ima zadatak osigurati neovisno, nepristrano i profesionalno sudstvo. ${ }^{64}$ U sastav VSTV-a ulazi 15 članova od kojih je šest sudaca, ${ }^{65}$ pet tužitelja ${ }^{66}$ dva odvjetnika ${ }^{67}$ te dva člana koja ne dolaze iz pravosuđa, $s$ tim da jednog člana bira Zastupnički dom Parlamentarne skupštine $\mathrm{BiH}$, a koji ne obavlja pravosudnu funkciju i nije iz reda zastupnika Parlamentarne skupštine $\mathrm{BiH}$, a drugog člana bira Vijeće ministara $\mathrm{BiH}$ na prijedlog ministra pravosuđa $\mathrm{BiH}$, a koji ne obavlja pravosudnu funkciju i nije član Vijeća ministara BiH. ${ }^{68}$ Premda u članstvu Vijeća suci ne predstavljaju većinu, time nisu narušeni preporučeni standardi. Ovo iz

Vidi čl. 6. st. 3. Ustava FBiH.

Vidi glava V. 4., čl. 11. st. 3. Ustava FBiH.

Vidi glava VI., čl. 7. st. 3. Ustava FBiH.

Parlamentarna skupština Bosne i Hercegovine na sjednici Zastupničkog doma, održanoj 11. svibnja 2004. godine, i sjednici Doma naroda, održanoj 21. svibnja 2004. godine, usvojila je Zakon o Visokom sudbenom i tužiteljskom vijeću Bosne i Hercegovine (u daljnjem tekstu - Zakon o VSTV-u BiH), objavljen u Službenom listu BiH, br. 25/04.

Vidi čl. 1. st. 2. Zakona o Visokom sudbenom i tužiteljskom vijeću Bosne i Hercegovine (dalje Zakon o VSTV-u BiH), „Službeni list BiH br. 25/04, 93/05, 15/08 i 48/07 i 15/08.“

Vidi čl. 3. st. 1. Zakona o VSTV BiH.

Po jedan sudac iz Suda BiH, Vrhovnog suda RS, Vrhovnog suda FBiH, županijskog ili općinskog suda, okružnog ili osnovnog suda i Suda Brčko Distrikta. Sve ove suce biraju međusobno suci iste razine, izuzev sudaca Brčko Distrikta koje bira Pravosudna komisija Brčko Distrikta. Vidi čl. 4. st. 1. točke a, c, e, g, i. Zakona o VSTV-u BiH. Ovdje je važno naglasiti da Pravosudna komisija Brčko Distrikta ima mogućnost izabrati ili suca ili tužitelja, tako da je broj sudaca u zavisnosti od izbora Pravosudne komisije i može iznositi pet ili šest. Vidi čl. 4. st. 1. točke a, c, e, g, i k. Zakona o VSTV-u BiH.

Po jedan tužitelj iz Tužiteljstva $\mathrm{BiH}$, Federalnog tužiteljstva FBiH, Republičkog tužiteljstva RS, županijskog tužiteljstva i okružnog tužiteljstva. Sve njih biraju međusobno tužitelji iste razine. Ibid, čl. 4. st. 1. točke b, d, f, h, j.

Jednog odvjetnika bira Odvjetnička komora $\mathrm{FBiH}$, a drugog Odvjetnička komora RS. Ibid, član 4. st. 1. točke $1, \mathrm{~m}$.

Vidi član 4. stav. 1. točke n, o. Zakona o VSTV-u BiH. 
razloga jer je tužiteljstvo u Bosni i Hercegovini organizirano na jednak način kao i sudstvo, odnosno tužitelji se imenuju i smjenjuju na isti način kao i suci, pa su preporučeni standardi u pogledu sastava tijela koje imenuje suce i tužitelje u potpunosti zadovoljeni. U odnosu na dva člana koja dolaze izvan pravosuđa, zaključuje se da se na takav način djelomično osigurava i sustav javne kontrole rada ovog tijela.

Jamstvo neovisnog i nepristranog suda zajamčeno je i odredbom čl. 3. st. 1. Zakonom o sudovima u FBiH koja propisuje da su sudovi samostalni i neovisni od zakonodavne i izvršne vlasti. ${ }^{69}, 70$ Odredbom čl. 3. st. 1. Zakona o sudovima RS ${ }^{71}$ propisano je da su sudovi samostalni i neovisni od zakonodavne i izvršne vlasti i zabranjen je svaki oblik utjecaja na donošenje sudskih odluka.

Osim prava na neovisan i nepristran sud, odredbom čl. 4. ZS FBiH zajamčeno je pravo zakonito osnovanog suda. ${ }^{72}$

Može se zaključiti da je amandmanima visokog predstavnika na entitetske ustave kojima se na ustavnoj razini entiteta jamči samostalno i neovisno sudstvo od izvršne i zakonodavne vlasti u bosanskohercegovačkom zakonodavstvu uspostavljeno pravo na neovisan sud, kao temeljno pravo, onako kako je on shvaćen u odlukama ESLJP. Nadalje, da je samostalnost sudačke vlasti od ostalih dviju grana vlasti podržana osnivanjem neovisnog, pravosudnog tijela VSTV-a BiH, te da su ova jamstva detaljno razrađena u zakonskim odredbama, prvenstveno Zakonom o sudovima u FBiH, Zakonom o sudovima u RS-a, Zakonom o sudovima u BD $\mathrm{BiH}$ i Zakonom o VSTV-u.

\subsection{Nepristranost suda}

Načelo nepristranosti suca je u pravnom sustavu Bosne i Hercegovine zajamčeno odredbom čl. 3. st. 2. $\mathrm{ZS} \mathrm{FBiH}^{73}$ kojim je propisano da nitko ne smije utjecati na neovisnost i nepristranost suca pri odlučivanju u predmetima koji su

69 Vidi čl. 3. Zakona o sudovima u FBiH, "Službene novine FBiH," br. 380/5, 22/06 i 63/10, s ispravkom u br. 72/10, 7/13 - dalje ZS FBiH.

Istovjetne su odredbe čl. 3. Zakona o sudovima Brčko Distrikta $\mathrm{BiH}$, "Službeni glasnik Brčko Distrikta BiH," br. 19/07, 20/07, 20/07 (ispravka), 39/09 i 31/114 - dalje ZS BD.

71 Vidi čl. 3. Zakona o sudovima RS, "Službeni glasnik RS," br. 37/12 - dalje ZS RS.

72 Istovjetne su odredbe čl. 5. ZS RS, te čl. 4. ZS BD.

73 Istovjetna je odredba čl. 3. st 3 ZS BD. Čl. 3. st. 2. ZS RS je propisano da sudovi u svom radu postupaju nepristrano i odluke donose u razumnom roku, dok je st. 3. propisano da nitko ne smije utjecati na neovisnost i nepristranost suca pri odlučivanju u predmetima koji su mu dodijeljeni. 
mu dodijeljeni u rad, dok je odredbom čl. 5. st. $2{ }^{74}$ istog zakona propisano da sudovi u svom radu postupaju nepristrano, pravodobno i učinkovito. Ovo načelo je detaljno razrađeno kroz odredbe Kodeksa sudačke etike kroz elemente ponašanja suca na sudu i izvan suda, u privatnim i službenim poslovima, sudjelovanja u građanskim, dobrotvornim i vjerskim aktivnostima, nespojivosti s političkim aktivnostima, davanje komentara u javnosti ili privatno, osobne odnose $\mathrm{s}$ pripadnicima pravne profesije, te specifične uvjete za izuzeće. ${ }^{75}$ Kodeks je usvojio i objavio VSTV 2006. godine na temelju svojih nadležnosti propisanih člankom 17. točkom 29. Zakona o VSTV.

Ustavni sud Bosne i Hercegovine (dalje - Ustavni sud BiH) u svojoj je praksi u cijelosti prihvatio pravna stajališta Europskog suda kad je riječ o pravu na neovisan sud. ${ }^{76}$ Međutim, prilikom utvrđivanja povrede čl. 6. stavak 1. EKLJP i člana II/3.e) Ustava BiH apelant je dužan konkretno navesti razloge zbog kojih smatra da je postupak pred sudom/sudovima bio nepravičan, kao i one zbog čega tvrdi da se oni ne mogu smatrati nepristranim sudovima, te priložiti dokaze u vezi svojih navoda ${ }^{77}$ jer u protivnom neće biti povrede prava na pravično suđenje. ${ }^{78}$

\subsection{Način imenovanja sudaca i trajanje sudačkih mandata}

Provođenje postupka imenovanja nositelja pravosudnih funkcija je osnovna nadležnost VSTV-a BiH kako bi se osigurala neovisnost i nepristranost sudova $\mathrm{u} \mathrm{BiH}$. Imenovanje se provodi nakon objavljivanja javnog natječaja, ${ }^{79}$ a nakon toga predsjednik Vijeća između članova Vijeća imenuje podvijeća za predlaga-

$74 \quad$ Istovjetna je odredba čl. 3. st 4 ZS BD.

75 Vidi točku 2. Kodeksa sudačke etike, dostupno na: https://www.pravosudje.ba

Tako je u odluci broj: AP 98/04 od 28. travnja 2004. godine Ustavni sud BiH zaključio da je sud bio nepropisno sastavljen jer je u vijeću tog suda u donošenju odluke sudjelovala sutkinja koja je morala biti izuzeta kako bi se osiguralo nepristrano suđenje, s obzirom da je njen suprug bio zastupnik oštećenog u predmetnom postupku, radi čega je zaključio da apelantu nije bilo osigurano pravično suđenje pred nepristranim sudom u smislu člana II/3.e) Ustava BiH i člana 6. stav 1. EKLJP. Vidi odluku Ustavnog suda BiH br. AP 98/04 od 28. travnja 2004. godine, objavljena u Službenom glasniku BiH, broj 30/04. Pogledaj i odluku Ustavnog suda BiH br. AP 1513/06 od 12. lipnja 2008. godine, objavljena u Službenom glasniku BiH, broj 91/08 i odluku Ustavnog suda BiH, br. AP 2107/12 od 24. travnja 2015., objavljena u Službenom glasniku BiH, broj 44/15.

Vidi odluku Ustavnog suda BiH br. AP 45/02 od 30. lipnja 2004. godine, objavljena u Službenom glasniku Bosne i Hercegovine, broj 41/04. Službenom glasniku Bosne i Hercegovine, broj 68/06. 
nje kandidata. ${ }^{80}$ Značajan iskorak u procesu objektivizacije i unapređenja sustava izbora i imenovanja nosilaca pravosudnih funkcija u $\mathrm{BiH}$ učinjen je uvođenjem kvalifikacijskog testiranja kandidata, koje obuhvaća različite pravne oblasti, ${ }^{81} \mathrm{koji}$ se prijavljuju na pozicije sudaca. Postupak izbora mora jamčiti da osobe koje se biraju na sudačke pozicije imaju visoke moralne kvalitete i sposobnosti, potrebno znanje, kvalifikacije i vještine neophodne za obavljanje ovih dužnosti, ${ }^{82}$ zatim jednaka prava i zastupljenost konstitutivnih naroda i ostalih, te imati za cilj i postizanje jednakosti spolova ${ }^{83}$ Odluka o imenovanju sadrži obrazloženje u pisanoj formi. Vijeće o svojoj odluci o imenovanju obavještava sve kandidate, odgovarajući sud i Ministarstvo pravosuđa. Odluka o imenovanju objavljuje se i u Službenom glasniku Bosne i Hercegovine. ${ }^{84}$ Protiv odluke o imenovanju nije dopuštena žalba, što je u suprotnosti s EKLJP koja predviđa da svaka osoba mora imati pravo izjaviti žalbu na po njega nepovoljnu odluku. Efektivnost ili djelotvornost pravnog lijeka ogleda se u tome da čovjek može, u slučaju da je njegovo ljudsko pravo prekršeno, da se ili ponovo uspostavi to pravo ili da mu se, ako to nije moguće, omogući naknada štete. Upravo zato EKLJP naglašava nužnost omogućavanja ostvarenja proklamiranih ljudskih prava i temeljnih sloboda ${ }^{85}$ Iznimno, Vijeće može poništiti odluku o imenovanju ako nakon donošenja odluke o imenovanju, a prije nego što imenovani sudac ili tužitelj preuzme dužnost, dobije podatke koji bi, da su bili poznati u vrijeme imenovanja, predstavljali razlog da Vijeće ne donese odluku o imenovanju. ${ }^{86,87}$

Vidi član 37. i 38. Zakona o VSTV-u BiH.

Vidi čl. 7. Pravilnika o kvalifikacijskom testiranju kandidata za pozicije nositelja pravosudnih funkcija u pravosuđu Bosne i Hercegovine, "Službeni glasnik BiH," br. 78/14.

Vidi čl. 7. Poslovnika o izmjenama i dopunama Poslovnika Visokog sudbenog i tužiteljskog vijeća Bosne i Hercegovine, "Službeni glasnik BiH," br. 41/18, dalje - Izmjene Poslovnika VSTV-a iz 2018.

Vidi čl. 43. st. 2. Zakona o VSTV-u BiH.

Vidi čl. 45. Zakona o VSTV-u.

Vidi kod Sadiković, Ć., Evropsko pravo ljudskih prava, Sarajevo, 2001., str. 113.

Vidi čl. 44. st. 2. Zakona o VSTV-u.

Ovdje je značajno istaći da je VSTV BiH prvi i jedini put iskoristio ovu svoju mogućnost u slučaju imenovanja sudaca u Općinskom sudu u Čitluku. Tako je na sjednici VSTV-a BiH održanoj 9. veljače 2017. godine, uvažavajući prigovore kandidata u natječajnoj proceduri, koji su prigovarali nacionalnoj i spolnoj diskriminaciji, a cijeneći da prilikom donošenja odluke Vijeće nije imalo na raspolaganju sve informacije koje je trebalo imati, poništilo odluke o imenovanju sudaca u Općinski sud u Čitluku, te zadužilo nadležno podvijeće da pripremi novi prijedlog za imenovanje. Vidi izvještaj sa sjednice VSTV-a BiH održane dana 8. i 9. veljače 2017. godine, https://vstv.pravosudje.ba 
Trajanje sudačke funkcije zajamčeno je odredbama Zakona o VSTV-u BiH, te je u skladu s preporukom europskih standarda ${ }^{88}$ da imenovani suci imaju zajamčen mandat dok ne navrše godine starosti koje su potrebne za obvezan odlazak u mirovinu. Tako je u Zakonu o VSTV-u propisano da se suci i tužitelji svih razina imenuju na mandat neograničenog trajanja, s tim što im mandat može prestati $u$ slučaju da podnesu ostavku, navrše starosnu dob propisanu za obvezan odlazak u mirovinu ili budu smijenjeni s dužnosti iz razloga utvrđenih zakonom. ${ }^{89}$

\section{Zaključak}

U svakom demokratskom društvu osnova vladavine prava počiva na trodiobi vlasti. Da bi se ona uistinu ostvarila, neovisnost i nepristranost suda mora biti postavljena kao temeljno pravno načelo. ESLJP je kroz opsežnu sudsku praksu utvrdio kriterije koji jamče ostvarenje i provedbu ovog temeljnog pravnog načela, poput načina izbora sudaca, trajanje njihovih mandata, postojanje jamstava za zaštitu od vanjskih pritisaka, kao i pitanje ostavlja li domaći sud dojam neovisnosti. Nakon osamostaljenja Bosna i Hercegovina je naslijedila pravni sustav u kojem je bilo dominantno načelo jedinstva vlasti. Početak istinski neovisnog i nepristranog sudstva označile su dvije odluke visokog predstavnika od 23. svibnja 2002. godine kojima je proglasio amandmane na entitetske ustave, kao i donošenje i usvajanje jedinstvenog Zakona o VSTV BiH. Ovim amandmanima se na ustavnoj razini entiteta jamči samostalno i neovisno sudstvo od izvršne i zakonodavne vlasti u bosanskohercegovačkom zakonodavstvu, čime je uspostavljeno pravo na neovisan sud, kao temeljno pravo, onako kako je ono shvaćeno u odlukama ESLJP. Međutim, zakone kojima se jamči ovo pravo Bosna i Hercegovina je donijela pod nadzorom međunarodne zajednice, što znači da Bosna i Hercegovina u budućnosti mora pokazati spremnost sama napraviti određene daljnje korake u dosljednoj primjeni i ostvarenju ovog načela, kako u teoriji, tako i u primjeni i praksi, jer se neovisno sudstvo, kao ni demokracija, ne može uvesti dekretom ili odlukama međunarodne zajednice.

Promatrajući u radu načelo neovisnog i nepristranog suda, javljaju se pitanja koja bi trebalo razmotriti. Prije svega u Ustav $\mathrm{BiH}$, kao najvišem pravnom aktu jedne države, de lege ferenda trebalo bi unijeti dopunu da je sudska vlast samostalna i neovisna od izvršne i zakonodavne vlasti. Isto tako u Zakonu o VSTV-u BiH de lege ferenda trebalo bi unijeti izmjenu da je protiv odluke o imenovanju nositelja

88 Vidi princip III. stav 3. Preporuke CM / Rec (2010) 12, član 12. Osnovnih načela UN.

89 Vidi član 23. - 32. Zakona o VSTV-u BiH. 
pravosudnih funkcija dopušten pravni lijek, pravo na žalbu, čime bi se odredbe o imenovanju sudaca u pogledu dopuštenosti djelotvornog pravnog lijeka uskladile s odredbama čl. II/1 Ustava BiH i čl. 13. EKLJP.

\section{THE RIGHT TO AN INDEPENDENT AND IMPARTIAL COURT UNDER ARTICLE 6 OF THE EUROPEAN CONVENTION FOR THE PROTECTION OF HUMAN RIGHTS AND FUNDAMENTAL FREEDOMS AND IN THE LEGISLATION OF BOSNIA AND HERZEGOVINA}

The independence and impartiality of the courts is one of the most important conditions for due process. The constitution, laws, and even state policy itself must insure the existence of such a judicial power that will be truly independent from other branches of government. Article 6, paragraph 1 of the European Convention for the Protection of Human Rights and Fundamental Freedoms states that everyone has the right to an independent and impartial tribunal established by law. By incorporating the European Convention for the Protection of Human Rights and Fundamental Freedoms into its constitutional order, Bosnia and Herzegovina made a commitment to adapt its legislation to the protection of rights under that convention.

This paper will analyze the praxis of the European Court of Human Rights in relation to the right to an independent and impartial tribunal established by law. This praxis has established a number of criteria that guarantee the realization and implementation of this fundamental legal principle. The second part of this paper will consider the right to an independent and impartial tribunal established by law in the legislation of Bosnia and Herzegovina. Afterwards it will try to answer the questions of whether and to what extent Bosnia and Herzegovina has aligned its legislation with the requirements of the right to a fair trial under Article 6, paragraph 1 of the European Convention for the Protection of Human Rights and Fundamental Freedoms in relation to a fundamental legal principle - an independent and impartial tribunal established by law.

Keywords: independence, impartiality, court, European Conventions for the Protection of Human Rights and Fundamental Freedoms. 